\title{
Yield and Yield Components of Sweet Potato as Influenced by Plant Density: In Adami Tulu Jido Kombolcha District, Central Rift Valley of Ethiopia
}

\author{
Teshome Abdissa ${ }^{1 \star}$, Amenti Chali ${ }^{1}$, Kassaye Tolessa $^{1}$, \\ Fiseha Tadese ${ }^{1}$ and Geremew Awas ${ }^{1}$ \\ ${ }^{1}$ Adami Tulu Agricultural Research Center, P. O. Box, 35 Ziway, Ethiopia.
}

Received $11^{\text {th }}$ January 2011

Research Article

Accepted $29^{\text {th }}$ January 2011

Online Ready $10^{\text {th }}$ February 2011

\begin{abstract}
Two best performing, morphologically different sweet potato varieties namely, Balella and Bareda, were used to determine optimum spacing between plants and rows in central rift valley of Ethiopia by participating different influential factors from the commencement of the activity. The results indicated that total tuber yield of Balella $\left(644 \pm 105 \mathrm{q} \mathrm{ha}^{-1}\right)$ performed better with spacing $20 \mathrm{~cm} \times 80 \mathrm{~cm}$ than the rest of the treatments i.e., $20 \mathrm{~cm} \times 60 \mathrm{~cm}\left(590 \pm 104 \mathrm{q} \mathrm{ha}^{-1}\right)$ and $50 \times 60$ $\mathrm{cm}\left(522 \pm 137 \mathrm{q} \mathrm{ha}^{-1}\right)$. But the net marketable yield obtained at spacing combination of $20 \mathrm{~cm} \mathrm{x}$ $60 \mathrm{~cm}\left(590 \pm 104 \mathrm{q} \mathrm{ha}^{-1}\right)$ was by far better being followed by $20 \mathrm{~cm} \times 80 \mathrm{~cm}$ and $50 \mathrm{~cm} \times 60 \mathrm{~cm}$ that gave average yield of $583 \pm 82 \mathrm{q} \mathrm{ha}^{-1}$ and $463 \pm 93 \mathrm{q} \mathrm{ha}^{-1}$, respectively. Correlation matrix of dependent variables resulted that green top weight was significantly correlated with total and marketable root yield $\left(0.887^{\star *}\right.$ and $0.846^{* *}$, respectively). This indicated that variation in total root yield and marketable root yield was accounted by the linear function of total green top yield $r^{2}=78.7 \%$ and $r^{2}=71.6 \%$, respectively. For Bareda, $20 \mathrm{~cm} \times 60 \mathrm{~cm}$ spacing gave total yield of 409 $\pm 257 \mathrm{q} \mathrm{ha}^{-1}$ followed by $20 \mathrm{~cm} \times 100 \mathrm{~cm}$ and $30 \mathrm{~cm} \times 60 \mathrm{~cm}$ that gave yield of $347 \pm 139 \mathrm{q} \mathrm{ha}^{-1}$ and $294 \pm 63 \mathrm{q} \mathrm{ha}^{-1}$, respectively. The correlation of green top and total root yield obtained for Bareda was strong and positive $\left(r=0.689^{* *}\right)$.
\end{abstract}

Keywords: FRG, Sweet potato, spacing and yield; 


\section{ABBREVIATIONS}

FRG: Farmer Research Group; Q/ha: Quintal per hectare; RD: Root Diameter; RL: Root Length; GT: Green Top; MR: Marketable; UMR: Unmarketable; TQ: Total Quintal; SAS: Statistical Analysis System; DA: Development Agent; Kg: kilogram; cm: centimeter; CV: coefficient of variation.

\section{INTRODUCTION}

Among the most important root and tuber crops, Sweet potato (Ipomea batatus L.) is one of the major traditional food crops of Ethiopia (Endale et al., 1994). It is an attractive crop among farmers due to its high productivity, universal uses, high caloric content and good taste. It is a known crop gifted with high potential to tolerant adverse environmental conditions such as drought, low soil fertility, high rainfall and it requires very little labor and care compared to other crops (CIP, 1995). Fresh sweet potato provides about 50\% more calories than Irish potato (Backumisky, 1983). Apart from its high caloric content, sweet potato is also one of the cheapest potential sources of vitamin A to alleviate problem of night blindness and infant mortality from which millions of children from sub-Saharan Africa are facing. With all its desirable traits, Sweet potato greatly contributes to food security and farmers' income (Terefe, 1994).

Based on CSO report of 1993/94 the national average yield of sweet potato in Ethiopia was 7 tons per hectare. However, previous 2006 and 2007 research result of Adami Tulu Agricultural Research Center (ATARC) reported the yield up to 37.1 tons per hectare from improved varieties. This indicates that the national as well as the regional yield is by far lower than the attainable yield obtained at research station. There are a number of constraints that hinder the production and productivity of sweet potato under farmers' circumstances. Among these, lack of appropriate agronomic practices has been a limiting factor and farmers are complaining of difficulty in management activities for different varieties (like those having long vine and horizontal root growth system and the other short vine and roots developing vertically downward). Therefore, evaluation and selection of different inter and intra row spacing by participating farmers based will improve production and productivity of the crop, which has great contribution for increment of the national average yield. Therefore, this research was done with the objectives

- To identify optimum inter and intra row spacing for two sweet potato varieties and

- To increase farmers' abilities and participation in conducting research activities

\section{MATERIALS AND METHODS}

\subsection{DESCRIPTION OF THE STUDY AREA}

The peasant association is located $2.5 \mathrm{~km}$ western of Adami Tulu Agricultural Research Center that is located in the central rift valley (CRV), $167 \mathrm{~km}$ south of Addis Ababa on Awassa road. It lies at a latitude of $7^{\circ} 9^{\prime} \mathrm{N}$ and $38^{\circ} 7^{\prime} \mathrm{E}$ longitude. It has an altitude of 1650 meter above sea level and a bimodal unevenly distributed average annual rainfall of $760 \mathrm{~mm}$. Rainfall extends from February to September with a dry period in May to June, which separates the preceding "short" rains from the following "long" rains. The $\mathrm{pH}$ of soil is 7.88 fine sandy loams with sandy clay having sand, silt, clay in proportion of $34 \%, 48 \%$ and $18 \%$ respectively (Adami Tulu Research Center profile, 1998). 


\subsection{EXPERIMENTAL METHODOLOGY}

The experiment was conducted on three groups of target farmers field organized as FRG (Farmers' Research Group) that had been participating in production of the crop starting from variety screening and selection during the year 2006 and 2007. Among many of the farmers, those three were selected based on interest to work in groups, able to provide trial land and willing to organize and work with the rest member farmers starting from land preparation up to best treatment selection. Two best performing varieties in the area; Bareda and Belela were selected because of morphological representation of the sweet potato varieties cultivated by those farmers living in the district and high amount of yield obtained per unit area of land. General description of the two varieties has been given in Table 1. A group of multidisciplinary researchers and DA (Development Agents) together with those farmers suggested twelve treatments including check $(30 \mathrm{~cm} \times 60 \mathrm{~cm})$ between plants and rows, respectively. Four level of spacing between two consecutive plants with in a row (20,30, 40 and $50 \mathrm{~cm}$ ) and three levels between two consecutive rows $(60,80,100 \mathrm{~cm})$ forming twelve treatments as follows: $20 \mathrm{~cm} x$ $100 \mathrm{~cm}, 20 \mathrm{~cm} \times 60 \mathrm{~cm}, 20 \mathrm{~cm} \times 80 \mathrm{~cm}, 30 \mathrm{~cm} \times 100 \mathrm{~cm}, 30 \mathrm{~cm} \times 60 \mathrm{~cm}, 30 \mathrm{~cm} \times 80 \mathrm{~cm}, 40 \mathrm{~cm} \times$ $100 \mathrm{~cm}, 40 \mathrm{~cm} \times 60 \mathrm{~cm}, 40 \mathrm{~cm} \times 80 \mathrm{~cm}$ and $50 \mathrm{~cm} \times 100 \mathrm{~cm}$ between plants and rows respectively were investigated. Uniform vine of $45 \mathrm{~cm}$ long from the top was used and planted at the onset of main rainy season June 2007 and harvesting was done after four months when physiological maturity and better tuber development attained. All agronomic practices like weeding, earthing up and other routine activities were conducted as per the recommendation set for the crop. However, fertilization was not applied because of good yield obtained during variety screening without any input.

\subsection{STATISTICAL ANALYSIS}

All the collected agronomic data was analyzed using SAS statistical package at $95 \%$ confidence interval. If there were significant difference among treatments, mean separation was made using Duncan Multiple Range Test (DMRT) for root diameter $(\mathrm{cm})$, root length $(\mathrm{cm})$, Green top $(\mathrm{Kg})$, Marketable weight in $\left(\mathrm{q} \mathrm{ha} \mathrm{h}^{-1}\right)$, unmarketable yield $\left(\mathrm{q} \mathrm{ha} \mathrm{h}^{-1}\right)$, total yield $\left(\mathrm{q} \mathrm{ha} \mathrm{h}^{-1}\right)$. To determine the strength of relationship among dependent variables correlation matrix was done using Gen-stat version (7.2).

\section{RESULTS AND DISCUSSION}

\subsection{PARTICIPATORY RESEARCH APPROACH VIEWED AS TECHNOLOGY ADOPTION}

In the past many years due to lack of awareness, participating farmers having rich pool of indigenous knowledge in technology generation has not been done. As a result many of the research outcome generated by researchers were not readily accepted and adopted by farmers that made it shelved after completion in Ethiopia in general and in the study area in particular. However, currently the government of Ethiopia set strategy of research development by involving the important key factors like farmers, local and international NGOs working with and for farmers, Ministry of Agriculture, etc. who have direct and indirect contribution for the ultimate technology adoption. As a result, stake holder identification, training, role, and responsibility sharing was made before the commencement of the field plantation. At the time of maturity, field day and visit were organized to evaluate the performance of the crop and for awareness creation.

\subsection{BELELLA VARIETY}

The statistical analysis of Belella (variety with short vine and roots developing vertically down 
ward) showed that there were high significant difference for all the yield estimate parameters except total unmarketable yield that gave nonsignificant difference at $p<0.05$ (Table 2). As regard to average root diameter per plant, spacing of $20 \mathrm{~cm} \times 100 \mathrm{~cm}$ gave the highest thickness of $7.2 \pm 66 \mathrm{~cm}$ followed by $40 \mathrm{~cm} \times 100 \mathrm{~cm}$ and $50 \mathrm{~cm} \times 60 \mathrm{~cm}$ that gave thickness of $7 \pm 1.5 \mathrm{~cm}$ and $6.9 \pm 17 \mathrm{~cm}$, respectively. This result was similar with the findings of (Enus and Razzaque 1977) done at Bangladesh; the lowest root weight that highly correlated to root diameter and length $304.20 \mathrm{~g} /$ plant was obtained from the closer spacing $(15 \mathrm{~cm} \times 75 \mathrm{~cm})$ between plants and rows respectively. Root weight per plant was increased with increase in plant density and it was highest with the value of $693.82 \mathrm{~g} /$ plant. Bainco (1975) found similar result in potato, where increased plant density decreased the tuber weight per plant.

Table 1: General description of the two varieties

\begin{tabular}{|c|c|c|c|}
\hline \multirow{2}{*}{$\begin{array}{l}\text { SI. } \\
\text { No. }\end{array}$} & \multirow{2}{*}{ Characteristics } & \multicolumn{2}{|c|}{ Variety } \\
\hline & & Belella & Bareda \\
\hline 1 & Maturity period & $\begin{array}{l}\text { - Early (90-120) days in the study } \\
\text { area }\end{array}$ & Medium (90-150)days \\
\hline 2 & Root color & $\begin{array}{l}\text { - Light white while raw and yellow } \\
\text { when boiled }\end{array}$ & Deep white at both stage \\
\hline 3 & Taste & - Milder & Too sugary \\
\hline 4 & Market preference & - Moderate to high & Extremely demanded \\
\hline 5 & Root growth habit & $\begin{array}{l}\text { - Vertically downward(carrot root } \\
\text { system) } \\
\text { - Easy for farmers while they } \\
\text { harvest root for consumption and } \\
\text { market display }\end{array}$ & $\begin{array}{ll}\text { - } & \text { Grows horizontally } \\
\text { - } & \text { It is very complicated for } \\
\text { harvesting } \\
\text { - }\end{array}$ \\
\hline 6 & Vine development & $\begin{array}{l}\text { - Vertical up ward and free of soil } \\
\text { born disease and insect pest that } \\
\text { will be aggravated by rainfall } \\
\text { splash. } \\
\text { Easy to conduct different cultural } \\
\text { practice because of the } \\
\text { manageable vine. }\end{array}$ & $\begin{array}{l}\text { Grows horizontally, } \\
\text { affected by soil born } \\
\text { disease and insect pest } \\
\text { It is a tiresome and futile } \\
\text { activity for farmers while } \\
\text { they are doing different } \\
\text { cultural practices }\end{array}$ \\
\hline 7 & $\begin{array}{l}\text { Preference by } \\
\text { farmers }\end{array}$ & $\begin{array}{l}\text { Highly preferred because of easy } \\
\text { cultural practice, high yield and } \\
\text { early maturity }\end{array}$ & $\begin{array}{l}\text { Less preferred because of } \\
\text { difficulty in management, } \\
\text { disease incidence, low } \\
\text { yield and medium maturity }\end{array}$ \\
\hline
\end{tabular}

Source: Personal observation and long year practical experiences of research work with the crop

Values of total tuber yield indicated that Balella variety with spacing $20 \mathrm{~cm} \times 80 \mathrm{~cm}$ performed better yield $\left(644 \pm 105 \mathrm{q} \mathrm{ha}^{-1}\right)$ than the rest of the treatments $20 \mathrm{~cm} \times 60 \mathrm{~cm}$ and $50 \mathrm{~cm} \times 60 \mathrm{~cm}$, with the yield value of $590 \pm 104 \mathrm{q} \mathrm{ha}^{-1}$ and $522 \pm \square 137 \mathrm{q} \mathrm{ha}^{-1}$, respectively. But the net marketable yield obtained at spacing combination of $20 \mathrm{~cm} \times 60 \mathrm{~cm}\left(590 \pm \square 104 \mathrm{q} \mathrm{ha}^{-1}\right)$ was by far better followed by $20 \mathrm{~cm} \times 80 \mathrm{~cm}$ and $50 \mathrm{~cm} \times 60 \mathrm{~cm}$ that gave average yield of $583 \pm \square 8 \mathrm{q}$ $\mathrm{ha}^{-1}$ and $463 \pm 93 \mathrm{q} \mathrm{ha}^{-1}$, respectively. In the latter two spacing, the tuber got enough space for better absorption of water and nutrient that helped in extending and thickening of the root system. But this makes the tuber less preferred by the market because of higher cooking time, more fiber 
development, more susceptible to the attack of insects like weevil and extra fuel need.

The unmarketable yield was high at $20 \mathrm{~cm} \times 80 \mathrm{~cm}$ spacing, as majority of the tuber fell under the range of oversize i.e., $>500 \mathrm{~g} /$ tuber. Of all treatments $50 \mathrm{~cm} \times 60 \mathrm{~cm}$ spacing combination yielded highest unmarketable tuber yield $\left(88 \pm 124 \mathrm{q} \mathrm{ha}^{-1}\right)$ followed by $30 \times 100 \mathrm{~cm}\left(65 \pm 89 \mathrm{q} \mathrm{ha}{ }^{-1}\right)$ and $20 \mathrm{~cm} \times 80 \mathrm{~cm}\left(61 \pm 54 \mathrm{q} \mathrm{ha}^{-1}\right)$. This work is also in close agreement with the result obtained by Telleyrad (1981). This confirms that the plant density significantly increased the root size.

Root size was higher $(125.87 \mathrm{~g} / \mathrm{root})$ in wider spacing at $75 \mathrm{~cm} \times 60 \mathrm{~cm}$. Both $75 \mathrm{~cm} \times 40 \mathrm{~cm}$ and $75 \mathrm{~cm} \times 30 \mathrm{~cm}$ plant spacing produced identical root size. The lowest size of root was obtained from closer spacing $(75 \mathrm{~cm} \times 15 \mathrm{~cm})$. It showed that closer spacing produced roots with comparatively less weights.

As shown in Table 2, the CV of unmarketable $\mathrm{q} /$ ha was $136.9 \%$ that was very high and put it beyond the unacceptable limit of range. But sometimes it happened because of out layers with both maximum and minimum that had been obtained with different spacing combinations which put it under unmarketable range.

Table 2. Result of mean and standard error comparison of Balella variety on farm

\begin{tabular}{lllllll}
\hline Variable & $\begin{array}{l}\text { Root } \\
\text { Diameter } \\
\text { (cm) }\end{array}$ & $\begin{array}{l}\text { Root } \\
\text { Length } \\
(\mathbf{c m})\end{array}$ & $\begin{array}{l}\text { Green Top } \\
\mathbf{( K g )}\end{array}$ & $\begin{array}{l}\text { Marketable } \\
\text { Root (q/ha) }\end{array}$ & $\begin{array}{l}\text { Unmarketable } \\
\text { Root (q/h) }\end{array}$ & $\begin{array}{l}\text { Total Yield } \\
(\mathbf{q} / \mathbf{h a})\end{array}$ \\
\hline DF & 2 & 2 & 2 & 2 & 2 & 2 \\
$20 \times 100$ & $7.2 \pm .66 \mathrm{a}$ & $15 \pm 3.4 \mathrm{ab}$ & $3 \mathrm{E} 4 \pm 8 \mathrm{E} 3 \mathrm{ab}$ & $438 \pm 110 \mathrm{abc}$ & $42 \pm 21 \mathrm{a}$ & $479 \pm 116 \mathrm{abc}$ \\
$20 \times 60$ & $5.5 \pm .25 \mathrm{bcd}$ & $13 \pm .62 \mathrm{ab}$ & $2 \mathrm{E} 4 \pm 1 \mathrm{E} 4 \mathrm{ab}$ & $590 \pm 104 \mathrm{a}$ & $0 \pm 0 \mathrm{a}$ & $590 \pm 104 \mathrm{a}$ \\
$20 \times 80$ & $4.9 \pm .1 \mathrm{~d}$ & $14 \pm 2.2 \mathrm{ab}$ & $3 \mathrm{E} 4 \pm 2 \mathrm{E} 4 \mathrm{ab}$ & $583 \pm 82 \mathrm{a}$ & $61 \pm 54 \mathrm{a}$ & $644 \pm 105 \mathrm{a}$ \\
$30 \times 100$ & $6.1 \pm .25 \mathrm{abcd}$ & $15 \pm 2.2 \mathrm{ab}$ & $4 \mathrm{E} 4 \pm 4 \mathrm{E} 4 \mathrm{a}$ & $384 \pm 221 \mathrm{bcd}$ & $65 \pm 89 \mathrm{a}$ & $449 \pm 309 \mathrm{abc}$ \\
$30 \times 60$ & $5 \pm 1.1 \mathrm{~d}$ & $12 \pm 2.6 \mathrm{ab}$ & $2 \mathrm{E} 4 \pm 9 \mathrm{E} 3 \mathrm{ab}$ & $332 \pm 74 \mathrm{bcd}$ & $12 \pm 21 \mathrm{a}$ & $344 \pm 63 \mathrm{bc}$ \\
$30 \times 80$ & $5.6 \pm .63 \mathrm{bcd}$ & $14 \pm 2.2 \mathrm{ab}$ & $2 \mathrm{E} 4 \pm 1 \mathrm{E} 3 \mathrm{ab}$ & $288 \pm 1.3 \mathrm{~cd}$ & $12 \pm 21 \mathrm{a}$ & $300 \pm 110 \mathrm{bc}$ \\
$40 \times 100$ & $7 \pm 1.5 \mathrm{ab}$ & $15 \pm 1.4 \mathrm{ab}$ & $1 \mathrm{E} 4 \pm 5 \mathrm{E} 3 \mathrm{ab}$ & $285 \pm 43 \mathrm{~cd}$ & $57 \pm 81 \mathrm{a}$ & $323 \pm 68 \mathrm{bc}$ \\
$40 \times 60$ & $5.3 \pm .5 \mathrm{~d}$ & $14 \pm 1.2 \mathrm{ab}$ & $1 \mathrm{E} 4 \pm 5 \mathrm{E} 3 \mathrm{ab}$ & $324 \pm 36 \mathrm{bcd}$ & $12 \pm 20 \mathrm{a}$ & $336 \pm 27 \mathrm{bc}$ \\
$40 \times 80$ & $6 \pm 1.4 \mathrm{abcd}$ & $14 \pm 1.8 \mathrm{ab}$ & $1 \mathrm{E} 4 \pm 5 \mathrm{E} 3 \mathrm{ab}$ & $278 \pm 54 \mathrm{~cd}$ & $22 \pm 20 \mathrm{a}$ & $299 \pm 57 \mathrm{bc}$ \\
$50 \times 100$ & $5.4 \pm 0.29 \mathrm{~cd}$ & $16 \pm 3.6 \mathrm{a}$ & $4 \mathrm{E} 4 \pm 4 \mathrm{E} 4 \mathrm{ab}$ & $294 \pm 77 \mathrm{bcd}$ & $28 \pm 17 \mathrm{a}$ & $322 \pm 83 \mathrm{bc}$ \\
$50 \times 60$ & $6.9 \pm .17 \mathrm{abc}$ & $13 \pm 2.8 \mathrm{ab}$ & $2 \mathrm{E} 4 \pm 1 \mathrm{E} 4 \mathrm{ab}$ & $463 \pm 93 \mathrm{ab}$ & $88 \pm 124 \mathrm{a}$ & $522 \pm 137 \mathrm{ab}$ \\
$50 \times 80$ & $6.1 \pm 1.3 \mathrm{abcd}$ & $15 \pm .91 \mathrm{ab}$ & $1 \mathrm{E} 4 \pm 8 \mathrm{E} 3 \mathrm{ab}$ & $233 \pm 47 \mathrm{~d}$ & $28 \pm 32 \mathrm{a}$ & $260 \pm 38 \mathrm{c}$ \\
\hline CV\% & $\mathbf{1 3 . 5 1}$ & $\mathbf{1 5 . 1 3}$ & $\mathbf{6 6 . 5 5}$ & $\mathbf{2 4 . 3}$ & $\mathbf{1 3 6 . 9}$ & $\mathbf{2 8 . 1 2}$ \\
\hline
\end{tabular}

${ }^{*}$ Mean of the same letter across the row indicates non-significant difference among the treatments at $(p<0.05)$.

Key: Under size<100gms, Small size 100-200gms, Medium size200-400, Large size 400-500gms, Over size >500gms; Marketable includes (small size, medium and large size), unmarketable includes all diseased, malformed, over and under sized tubers respectively. 
Table 3. Results of SAS output (Mean \pm SE) of average treatments across different trial farmers as compared by different variables

\begin{tabular}{lllll}
\hline Variable & D.F. & Rep1 $^{\star}$ & Rep2 $^{\star}$ & Rep3 $^{\circledR}$ \\
\hline $\mathrm{RD}$ & 11 & $5.6 \pm .98 \mathrm{a}$ & $12 \pm 6.3 \mathrm{a}$ & $59 \pm .97 \mathrm{a}$ \\
$\mathrm{RL}$ & 11 & $14 \pm 1.5 \mathrm{ab}$ & $15 \pm 2.9 \mathrm{a}$ & $13 \pm 1.7 \mathrm{~b}$ \\
$\mathrm{GT}$ & 11 & $1 \mathrm{E} 4 \pm 6 \mathrm{E} 4 \mathrm{~b}$ & $4 \mathrm{E} 4 \pm 3 \mathrm{E} 4 \mathrm{a}$ & $2 \mathrm{E} 4 \pm 6 \mathrm{E} 3 \mathrm{~b}$ \\
$\mathrm{MR}$ & 11 & $342 \pm 102 \mathrm{~b}$ & $430 \pm 172 \mathrm{a}$ & $351 \pm 140 \mathrm{~b}$ \\
$\mathrm{UMR}$ & 11 & $45 \pm 50 \mathrm{a}$ & $43 \pm 56 \mathrm{a}$ & $10 \pm 16 \mathrm{a}$ \\
\hline TQ & 11 & $388 \pm 136 \mathrm{ab}$ & $470 \pm 189 \mathrm{a}$ & $360 \pm 142 \mathrm{~b}$ \\
\hline R= root diameter; & $R L=$ root length; GT green top; MR: Marketable; UMR: Unmarketable; TQ: Total \\
\hline
\end{tabular}

\subsubsection{YIELD PERFORMANCE ACROSS THE LOCATION}

For effective treatment performance, evaluation of the research findings should be done at different location to capture diversity of biotic factors. Biotic factors that have been really observed at farmers' situation were soil fertility variation, management difference among farmers, rainfall frequency and intensity variation. But before the starting of farmers participatory approach, for the last many years, research output doesn't consider the varietal performance across diversified location. As a result the yield outcome obtained at research station and recommended by researchers could not be attained at farmers' real diversified and working condition that led to no or low technology adoption. As indicated in the Table 2, except of root diameter the rest dependent variables (total tuber yield, marketable yield, green top and average root length) were highly significant and supporting the above justification. That means blocking the treatments across a location increase the precision of the experiment by removing the experimental error from treatments within a block.

The result of the correlation matrix indicated that green top weight is significantly correlated with total and marketable root yield $\left(0.887^{\star *}\right.$ and $0.846^{\star \star}$, respectively) (Table 4$)$.

Table 4. Correlation matrix of different dependent variables of variety Balella

\begin{tabular}{lllllllll}
\hline \multicolumn{7}{c}{ Correlation matrix Balella } \\
\hline GT & 1.000 & & & & & & \\
IL & $0.707^{* *}$ & 1.000 & & & & & & \\
MQ & $0.846^{* *}$ & $0.665^{* *}$ & 1.000 & & & & & \\
RD & 0.263 & 0.256 & 0.302 & 1.000 & & & & \\
RL & $0.502^{* *}$ & 0.499 & $0.574^{* *}$ & $0.520^{* *}$ & 1.000 & & & \\
RNP & 0.391 & $0.574^{* *}$ & 0.349 & 0.060 & 0.381 & 1.000 & & \\
RWP & $0.505^{* *}$ & 0.468 & $0.596^{* *}$ & 0.471 & $0.748^{* *}$ & 0.435 & 1.000 & \\
TQ & $0.887^{* *}$ & $0.630^{* *}$ & $0.980^{* *}$ & 0.306 & $0.578^{* *}$ & 0.343 & $0.628^{* *}$ & 1.000 \\
& $\mathrm{GT}$ & $\mathrm{IL}$ & $\mathrm{MQ}$ & $\mathrm{RD}$ & $\mathrm{RL}$ & $\mathrm{RNP}$ & $\mathrm{RWP}$ & $\mathrm{TQ}$ \\
\hline
\end{tabular}

$G T=$ green top; $I L=$ inter-node length; $M Q=$ marketable yield in quintal; $R D=$ root diameter; $R L=$ root length; $R N P=$ root number per plant; $R W P=$ root weight/plant; $T Q=$ total root yield in quintal.

That is variation in total root yield and marketable root yield were accounted by the linear function of total green top yield having $r^{2}=78.7 \%$ and $r^{2}=71.6 \%$, respectively. This finding agrees with the work of Zelalem et al. (2009) done on Irish potato that Positive and highly significant correlation was obtained between above and underground biomass $\left(r=0.77^{\star \star}\right)$ indicating the existence of 
close association between them. However various research activities done by different scholars (Mortia, 1969; Sadanandan, 1973; Revindran and Nambisa, 1987; Onwueme and Shinha, 1991), on diversified root and tuber crops indicated that more vegetative growth as the expense of tuber initiation and development for any treatment application that facilitate green top weight.

\subsection{BAREDA VARIETY}

It is clear form Table 5 that the general yield performance of the Bareda variety was much lower than that of yield obtained by Belella. In general $20 \mathrm{~cm} \times 60 \mathrm{~cm}$ spacing gave total yield of $409 \pm 257 \mathrm{q} /$ ha followed by $20 \mathrm{~cm} \times 100 \mathrm{~cm}$ and $30 \mathrm{~cm} \times 60 \mathrm{~cm}$ that gave $347 \pm 139 \mathrm{q} / \mathrm{ha}$ and $294 \pm$ $63 \mathrm{q} / \mathrm{ha}$, respectively. Among all the treatments $40 \mathrm{~cm} \times 100 \mathrm{~cm}$ gave the lowest performance $(129 \pm 69 \mathrm{q} / \mathrm{ha})$ followed by $50 \mathrm{~cm} \times 100 \mathrm{~cm}(144 \pm 34 \mathrm{q} / \mathrm{ha})$ and $30 \mathrm{~cm} \times 80 \mathrm{~cm}(185 \pm 111 \mathrm{q} / \mathrm{ha})$. It is indicative of the fact that if spacing between plant and rows increases beyond provision of enough nutrients, the net number of vine decreases resulting into lower yield, since the net number of vine is positively correlated with yield obtained at the end of the day.

Table 5. Result of Bareda variety on farm having twelve treatments (according to 2000 SAS version) with mean \pm Comparison

\begin{tabular}{lllllll}
\hline Variable & $\begin{array}{l}\text { Root } \\
\text { Diameter(cm) }\end{array}$ & $\begin{array}{l}\text { Root } \\
\text { length } \\
\text { (cm) }\end{array}$ & $\begin{array}{l}\text { Green } \\
\text { top(kg/ha) }\end{array}$ & $\begin{array}{l}\text { Marketable } \\
\text { root(q/ha) }\end{array}$ & $\begin{array}{l}\text { Unmarketable } \\
\text { root(q/ha) }\end{array}$ & $\begin{array}{l}\text { Total } \\
\text { root(q/ha) }\end{array}$ \\
\hline $\mathrm{DF}$ & 3 & 3 & 3 & 3 & 3 & 3 \\
$20 \times 100$ & $4.3 \pm 1 \mathrm{a}$ & $19 \pm 1.3 \mathrm{a}$ & $3 \mathrm{E} 4 \pm 3 \mathrm{E} 3 \mathrm{bcd}$ & $322 \pm 115 \mathrm{ab}$ & $25 \pm 27 \mathrm{a}$ & $347 \pm 139 \mathrm{ab}$ \\
$20 \times 60$ & $4.2 \pm 0.91 \mathrm{a}$ & $19 \pm 1.9 \mathrm{a}$ & $3 \mathrm{E} 4 \pm 2 \mathrm{E} 4 \mathrm{ab}$ & $396 \pm 267 \mathrm{a}$ & $13 \pm 11 \mathrm{a}$ & $409 \pm 257 \mathrm{a}$ \\
$20 \times 80$ & $4.4 \pm 102 \mathrm{a}$ & $17 \pm 2.6 \mathrm{a}$ & $4 \mathrm{E} 4 \pm 1 \mathrm{E} 4 \mathrm{a}$ & $220 \pm 3.7 \mathrm{abc}$ & $41 \pm 50 \mathrm{a}$ & $188 \pm 167 \mathrm{ab}$ \\
$30 \times 100$ & $4.8 \pm 1.4 \mathrm{a}$ & $20 \pm 2.0 \mathrm{a}$ & $3 \mathrm{E} 4 \pm 2 \mathrm{E} 4 \mathrm{bcd}$ & $270 \pm 164 \mathrm{abc}$ & $17 \pm 4.9 \mathrm{a}$ & $281 \pm 160 \mathrm{ab}$ \\
$30 \times 60$ & $3.6 \pm 1.2 \mathrm{a}$ & $19 \pm 3.2 \mathrm{a}$ & $2 \mathrm{E} 4 \pm 3 \mathrm{E} 3 \mathrm{bcd}$ & $290 \pm 71 \mathrm{abc}$ & $4.6 \pm 8 \mathrm{a}$ & $294 \pm 63 \mathrm{ab}$ \\
$30 \times 80$ & $4 \pm 1.4 \mathrm{a}$ & $21 \pm 1.2 \mathrm{a}$ & $2 \mathrm{E} 4 \pm 1 \mathrm{E} 4 \mathrm{bcd}$ & $176 \pm 103 \mathrm{bc}$ & $8.3 \pm 12 \mathrm{a}$ & $185 \pm 111 \mathrm{ab}$ \\
$40 \times 100$ & $5.5 \pm 1.2 \mathrm{a}$ & $20 \pm 5.2 \mathrm{a}$ & $2 \mathrm{E} 4 \pm 1 \mathrm{E} 4 \mathrm{~d}$ & $110 \pm 40 \mathrm{c}$ & $19 \pm 29 \mathrm{a}$ & $129 \pm 69 \mathrm{~b}$ \\
$40 \times 60$ & $5.3 \pm 0.66 \mathrm{a}$ & $21 \pm 309 \mathrm{a}$ & $3 \mathrm{E} 4 \pm 2 \mathrm{E} 4 \mathrm{abc}$ & $323 \pm 136 \mathrm{ab}$ & $6.9 \pm 12 \mathrm{a}$ & $330 \pm 132 \mathrm{ab}$ \\
$40 \times 80$ & $5.1 \pm 1.4 \mathrm{a}$ & $19 \pm 2.6 \mathrm{a}$ & $2 \mathrm{E} 4 \pm 1 \mathrm{E} 4 \mathrm{dc}$ & $220 \pm 131 \mathrm{abc}$ & $13 \pm 12 \mathrm{a}$ & $233 \pm 130 \mathrm{ab}$ \\
$50 \times 100$ & $5.7 \pm 1.4 \mathrm{a}$ & $17 \pm 0.81 \mathrm{a}$ & $1 \mathrm{E} 4 \pm 7 \mathrm{E} 3 \mathrm{~d}$ & $130 \pm 36 \mathrm{bc}$ & $14 \pm 4.1 \mathrm{a}$ & $144 \pm 34 \mathrm{~b}$ \\
$50 \times 60$ & $4 \pm 0.85 \mathrm{a}$ & $20 \pm 4.6 \mathrm{a}$ & $2 \mathrm{E} 4 \pm 4 \mathrm{E} 3 \mathrm{~d}$ & $170 \pm 74 \mathrm{bc}$ & $3.7 \pm 6.4 \mathrm{a}$ & $174 \pm 71 \mathrm{ab}$ \\
$50 \times 80$ & $5 \pm 2.2 \mathrm{a}$ & $19 \pm 0.6 \mathrm{a} 9$ & $1 \mathrm{E} 4 \pm 9 \mathrm{E} 3 \mathrm{~d}$ & $154 \pm 93 \mathrm{bc}$ & $27 \pm 19 \mathrm{a}$ & $181 \pm 109 \mathrm{ab}$ \\
$\mathrm{CV}(\%)$ & 14.2 & 12.81 & 31.9 & 42.86 & 138.16 & 50.14 \\
\hline
\end{tabular}

$D f=$ degree of freedom; $C V=$ coefficient of variation; *Mean of the same letter across the row indicates non significant difference among the treatments at $(p<0.05)$

Key: Under size<100, Small size 100-200gm, medium size200-400 gm, large size 400-500 gm, Over size >500g; Marketable tuber includes (small size, medium and large size), unmarketable tuber includes all diseased, malformed, over and under sized tubers respectively

Relative to Belella that showed strong and positive correlation among different dependent variables, Bareda resulted with weak correlation (Table 6). 
Table 6. Simple correlation coefficients among different dependent parameters for variety Bareda

\section{Correlation matrix among different dependent variables of Bareda variety}

\begin{tabular}{lllllllll}
\hline GT & 1.000 & & & & & & & \\
IL & 0.071 & 1.000 & & & & & \\
MQ & $0.635^{* *}$ & -0.258 & 1.000 & & & & \\
RD & -0.110 & 0.021 & 0.249 & 1.000 & & & \\
RL & 0.392 & 0.058 & 0.284 & 0.208 & 1.000 & & & \\
RNP & 0.427 & -0.016 & 0.383 & 0.006 & 0.214 & 1.000 & & \\
RWP & 0.088 & 0.206 & 0.323 & 0.473 & 0.264 & $0.542^{* *}$ & 1.000 & \\
TQ & $0.689^{* *}$ & -0.003 & $0.853^{* *}$ & 0.326 & 0.364 & $0.577^{* *}$ & $0.579^{* *}$ & 1.00 \\
& $\mathrm{GT}$ & $\mathrm{IL}$ & $\mathrm{MQ}$ & $\mathrm{RD}$ & $\mathrm{RL}$ & $\mathrm{RNP}$ & $\mathrm{RWP}$ & $\mathrm{TQ}$ \\
\hline
\end{tabular}

$G T=$ green top; I = inter-node length; $M Q=$ marketable yield in quintal; $R D=$ root diameter; $R L=$ root length; $R N P=$ root number per plant; $R W P=$ root weight/plant; $T Q=$ total root yield in quintal.

Similar to Belella, the correlation of green top and total root obtained for Bareda was also strong and positive $\left(r=0.689^{* *}\right)$. The correlation of total yield with that of root number per plant and root weight per plant were also positive and highly significant showing $r$ value of $r=0.577^{\star \star}$ and $r=0.579^{* *}$, respectively.

\section{CONCLUSIONS AND RECOMMENDATION}

Root and tuber crop in general and sweet potatoes in particular are the crops that need to be cultivated for food security for countries like Ethiopia where population is growing at alarming rate. It thrives best in areas where there is difficulty in field crop production that is pronounced due to current global warming from which many developing countries are suffering. There for it is paramount important to increase production and productivity of the crop by adopting different agronomic practices out of which working for optimum plant density is the major. Since Bareda represents those all varieties whose vine grows horizontally and that develop root roots divergent, the result obtained from finding holds true for the rest. Therefore, $20 \mathrm{~cm} \times 60 \mathrm{~cm}$ between two consecutive plants and rows should be adopted for those farmers involved in sweet potato production in central rift valley of Ethiopia. But for the variety Belella $(20 \times 80 \mathrm{~cm})$ between plants and rows respectively should be followed to come up with economical and dependable root yield.

\section{ACKNOWLEDGMENTS}

We express our heartfelt appreciation to Japan Government who has been dedicated to help developing country like Ethiopia both technically and financially. Really, without their fund and their technical assistance this paper would not have been materialized. Moreover, all staff members of horticulture research team who are involved in data collection, monitoring as well training of farmers and other stakeholders would be acknowledged. Lastly, for Oromiya Agricultural Research Institute who provides us many support throughout the experimenting period. 


\section{REFERENCES}

Abdissa, G. (1995). The potential contribution of Sweet potato to food and income security of farmers. On farm research out-put from Bako area. In Yohanse, D. et al. (eds). Proceeding of the $7^{\text {th }}$ Annual Conf. of the Crop Sci. Soc. of Ethiopia. 27-28 April 1995, Addis Ababa, Ethiopia.

Abule, E., Geremew, E., Aliye, H. (1998). Adami Tulu Agricultural Research Center, Bull. No. 1, Oromiya Agricultural Development Bureau Finfinne, Ethiopia.

Amanti, C., Teshome, A., Kasaye, T., Taha, M. (2009). On Farm Participatory Evaluation and Selection of Sweet potato (Early, Medium and Late set) varieties at Adami Tulu Jiddo Kombolcha District. Proc. $2^{\text {nd }}$ Ethiopian Horticultural Science Society. Ethiopian Institute of Agricultural Research. Addis Ababa, Ethiopia, 22-23 January, 2009.

Backumisky, G.V.U. (1983). Plant growing in the tropics and sub tropics, MIR, publisher, Moscow.

Bianco, V.V. (1975). Effect of weight of seed tubers and planting density on yield of potato tubers. Rivista di Agronomia 9 (2/3), 197-203.

Enus, M., Razzaque, M.A. (1977). Yield and grades of potato as affected by seed-tuber size and plant spacing. Bangladesh Hortic., 5(1), 21-28.

Endale, T., Terefe, B., Mukgeta, D., Geleta, L. (1994). Improvement studies on Enset and Sweet potato. In: proceedings of the second national Horticultural workshop in Ethiopia, 1-3 Dec.1992. Addis Ababa, Ethiopia.

Int. Potato Center (CIP). (1995). People centered research for sustainable production. Circular, Vol. 21 (21:1).

Morita, T. (1969). Effect of Nitrogen sources on the top growth, tuber formation and its development in sweet potato. J. Japan Sci., 11, 74.

Onwueme, I.C., Sinha, T.D. (1991). Field crop production in Tropical Africa, Principles and practice, CTA (Technical center for agriculture and rural cooperation) The Netherlands.

Ravindran, C.S., Bala, N. (1987). Effect of FYM and NPK on yield quality of sweet potato. J. Root Crops, 12(2), 111-112.

Talleyrand, H. (1981). Production of marketable and seed size roots for direct seedling of sweet potato through nutritional and cultural manipulations. Dissertation Abstracts Int., B 41(12) 4340.

Terefe, B., Geleta, L. (1994). Agronomic Studies on Sweet potato. In: proceedings of the second national Horticultural workshop in Ethiopia, 1-3 Dec.1992. Addis Ababa, Ethiopia.

Zelalem, A., Tekalign, T., Nigussie, D. (2009). Response of potato (Solanum tuberosum L.) to different rates of nitrogen and phosphorus fertilization on vertisols at Debre Berhan, in the central highlands of Ethiopia. Afr. J. Plant Sci. 3(2), 016-024.

(C) 2011 Abdissa et al.; This is an Open Access article distributed under the terms of the Creative Commons Attribution License (http://creativecommons.org/licenses/by/2.0), which permits unrestricted use, distribution, and reproduction in any medium, provided the original work is properly cited. 